\title{
Spatiale forklaringer
}

\author{
Da den geografiske tænkning \\ kom på den humanvidenskabelige dagsorden
}

Inden for de sidste 20-30 år har man kunnet registrere en såkaldt spatial vending (Soja 1989, Soja 1996, Massey 2005, Döring und Thielmann 2008), hvor man indenfor et stadig bredere felt af discipliner og forskningsområder er blevet optaget af at gentænke og udvikle geografiske forklaringer og begreber og udforske menneskelivets spatiale dimensioner. Man er i den forbindelse blevet stadig mere optaget af at udforske konsekvenserne af det forhold, at menneskelivet, erkendelsen og det sociale er rumligt situeret. Det samfunds- og kulturanalytiske vokabular er blevet beriget med en række rumlige metaforer og begreber som margen, mapping, grænse, deterritorialisering, reterritorialisering, sted, region, landskab, situerethed og lokalisering (Bachmann-Medick 2006: 304), og man har set en ambition om at sammentænke forskellige niveauer og dekonstruere binære oppositioner såsom det lokale og det globale, det tilhørende og det udgrænsede, det konkrete og det imaginære, praksis og repræsentation ${ }^{1}$. Vi ser med den spatiale vending en omfattende og flerfacetteret udforskning af rummets evne til at samle, rumme og situationere menneskelivet. Men hvorfor og hvordan rykker forholdet mellem det tidslige, det sociale og det spatiale ind i centrum af den analytiske bevidsthed i humanvidenskaberne? Hvis den spatiale vending ${ }^{2}$ er andet og mere end en forkærlighed for specifikke begreber og ord, hvori består så det andet og mere, som de topologisk funderede forklaringer og fokuseringen på rumlighedens betydningsdimensioner kan bringe til torvs? Det er spørgsmål, som denne artikel vil belyse gennem en udforskning af nogle af de transformationer af forståelsen af begreberne rum og sted, der kendetegner den spatiale vending. Dette vil dels ske gennem en præcisering af, hvad det er for indsigter i den sociale rumlighed, som henholdsvis den kritiske kulturgeografi, den fænomenologiske stedsteori og kulturstudiernes praksisanalyser bringer til torvs ${ }^{3}$, og dels gennem en efterfølgende udpegning af hvordan den igangværende spatiale vending er forbundet med vendingen mod 
praksis og materialitet.

Den spatiale vending er motiveret af en stigende opmærksomhed på, at måderne, man definerer, forstår og forvalter sted og rum på, har en række filosofiske, politiske og analytiske implikationer. I 2008 udkom Spatial Turn - Das Raumparadigma in den Kultur und Sożialwissenschaften på Verlag Bielefeld redigeret af Jörg Döring og Tristan Thielmann, og i 2009 udkom på Routledge The Spatial Turn - Interdisciplinary perspectives redigeret af Barney Wharf og Santa Arias. Disse værker falder på et tørt sted. I jagten på at udforske den spatiale vendings genealogi kan man til tider få fornemmelsen af at forfølge kejserens nye klæder, da mange refererer til og hævder at rekurere på en spatial vending og en stigende interesse for den geografiske tænkning. Men man skal lede længe efter forsøg på nærmere at bestemme dette begreb endsige dets oprindelse eller virkningshistorie.

Der har været en stor interesse for den spatiale vending indenfor studier af medier, teknologi og kommunikation. I 2002 afholdtes eksempelvis i Darmstadt en international konference med titlen Transforming Spaces. The Topological Turn in Technology Studies, der tematiserede de spatiale aspekter af forholdet mellem mennesker og teknologier. I 2006 udkom Geographies of Communication - The Spatial Turn in Media Studies der udforsker de spatiale aspekter af medier og kommunikation. I forordet argumenterer redaktørerne Jesper Falkheimar og Andre Jansson for, at mediestudier bør være placeret helt centralt i den spatiale vending, og i de genovervejelser over rummets betydning denne indebærer. En ikke ubetydelig kontekst for spatialitetens stigende betydning i de human- og samfundsvidenskabelige forklaringsmodeller er da også udviklingen af nye kortlægnings- og lokationsteknologier, visualiseringsværktøjer og datakilder ${ }^{4}$. I 2007 udkom Spatial theories of education: policy and geography matters, redigeret af Kalervo N. Gulson og Colin Symes, der rummer en række bidrag, som udforsker, hvordan undervisningssociologien kan beriges af spatiale teorier og taler for en spatial vending indenfor pædagogikken. Desuden udgav tidsskriftet Political Analysis i 2002 et særnummer om spatiale metoder i politisk teori (Vol 10 (3), 2002). Den spatiale vending ses ydermere perspektivrigt udfoldet indenfor såvel videnskabshistorie som historie i bredere forstand. Spændende redegørelser for den spatiale vendings nedslag i videnskabshistorien kan eksempelvis findes i både Charles W. J. Withers artikel "Place and the "Spatial Turn" in Geography and in History" (2009) og i Diarmid A. Finnegans "The Spatial Turn: geographical Approaches in the history of Science" (2008). Sidstnævnte viser blandt andet, hvordan den spatiale vending har medført en stigende interesse for at udforske, hvorledes den videnskabelige praksis er situeret og indlejret i specifikke sociale og spatiale kontekster (Finnegan 2008). 


\section{Den spatiale vendings genealogi}

Edward Soja gives sædvanligvis æren for at have navngivet og påbegyndt den mere omfattende diagnosticering af den spatiale vending i sin bog Postmodern Geographies - The Reassertion of Space in critical Social Theory (1989). Ifølge Soja begynder en række tænkere i slutningen af det 20. århundrede at tage rummet og de rumlige aspekter af menneskets væren i verden lige så alvorligt, som man - ikke mindst siden Hegel - har taget de historiske aspekter af menneskelivet (Soja 2008: 243). ${ }^{5}$ Begrebet spatial vending skulle vise sig at få en anvendelseshistorie af noget mere omfattende dimensioner, end man kan fremlæse af dets første anvendelse i underoverskriften "Uncovering Western Marxism's spatial turn" i kapitlet "History: Geography: Modernity" i Postmodern Geographies. Soja er i sin forskning optaget af rummets centrale betydning som konstitutiv for samfundet. Geografiske forklaringer kan ifølge Soja bidrage afgørende til forståelsen af økonomiske og sociale transformationer. Soja er stærkt inspireret af Henri Lefebvre og Michel Foucault, som han påpeger begge havde en ambition om at stille rumlig tænkning på niveau med historisk tænkning (Soja 2008: 251-252).

Det er i særlig grad to tekster af Foucault, der føres ind i manegen, når Foucault hædres som den spatiale tænknings bannerfører. Den ene er Des espaces autres (1969), den anden er et interview med Foucault fra 1976, der er trykt i tidsskriftet Herodoté. I Des espaces autres skriver Foucault, at vores tidsalder i modsætning til det historiebesatte 19. århundrede lader sig begribe som rummets tidsalder:

Det 19.århundrede har været besat af én stor tvangstanke, nemlig historien[...]. Vort århundrede er måske snarere rummets århundrede. Vi befinder os i det simultanes århundrede, i det sideordnedes, vi befinder os i århundredet for det nære og det fjerne, for det samlede og det spredte. Vi befinder os i en tid, hvor verden, tror jeg, opleves mindre som ét stort liv, der udvikler sig gennem tiden, end som et net, der forbinder punkter og fletter sine tråde (Foucault 1998 [1967]: 87).

Ifølge Foucault sker denne rummets renæssance på baggrund af en lang periode i tænkningens historie, hvor rummet har været forbundet med det døde, fikserede, ikke-dialektiske og immobile, hvorimod tiden er blevet forbundet med rigdom, liv, dialektik og frugtbarhed (Foucault 1980: 70). I ovenfor nævnte interview fra det marxistiske geografiske tidsskrift Hérodote fremhæver Foucault, at optagetheden af spatialitetens betydning ikke skal se som "anti-historie", men som et analyseperspektiv, der kan supplere, uddybe og komplementere den historiske analyse (Foucault 1980: 70-71). Herodots interviewere spørger vedholdende ind til geografiens placering i Foucaults vidensarkæologi. Men selv om Foucault medgiver, at han i 
sin søgen efter at forklare forholdet mellem viden og magt i rigt mål har tyet til spatiale metaforer, tøver han langt hen i interviewet med at ville sige noget egentligt om geografiens status såvel i som uden for hans egen tænkning. Til sidst anerkender han dog geografiens centrale placering og funktion som forbindelsesled mellem en række faktorer, han har forsøgt at forbinde i sin tænkning (Foucault 1980: 77). Geografiske problemstillinger optræder ofte integreret i andre tematikker hos Foucault og, som Stuart Elden og Jeremy W. Crampton har argumenteret for, mere som et analyseværktøj end som primært objekt for tænkningen (Elden \& Crampton 2007: 9). Foucaults indflydelse på den geografiske tænkning går ikke mindst gennem hans udforskninger af forbindelserne mellem viden, magt og rum. ${ }^{6}$ Konstellationen magt og viden udforskes i den postmoderne geografi gennem analyser af betydningen og forvaltningen af en række forskelskonstruerende identifikationsmarkører såsom køn, klasse, race, etnicitet, seksualitet, krop og religion. Det geografiske perspektiv bidrager i den forbindelse med indsigt i, hvordan disse socialt og kulturelt konstruerede forskelsmarkører får et rumligt udtryk i form af produktionen og opretholdelsen af forskellige spatialt producerede og manifesterede uligheder. Den postmoderne geografis postkoloniale perspektiv dekonstruerer, som vi skal se i det følgende, en række af disse identifikationsmarkører og binære begrebspar gennem en afdækning af, hvordan sociale og kulturelle identiteter er bevægelige, komplekse, fragmenterede og hybride.

\section{Rummet som socialt produceret}

Den eksistentialistiske og neomarxistiske filosof Henri Lefebvre (1901-1991) er ikke uden grund blevet hyldet som en af de mest indflydelsesrige blandt det 20 . århundredes sociologiske teoretikere. Han har sat sig væsentlige spor i den venstreintellektuelle diskurs og har haft stor indflydelse på den angloamerikanske humangeografi og ikke mindst den kritiske kulturgeografi. Flere af de mest indflydelsesrige postmodernistiske teoretikere som David Harvey og Edward Soja hævder, at en genopdagelse af Lefebvres kritiske projekt er mulighedsbetingelsen for deres egne teorier ${ }^{7}$. La Production de l'espace fra 1974 er hovedværket indenfor Lefebvres spatiale analysers 'anden fase', og er det værk, der har haft så absolut mest gennemslagskraft indenfor den geografiske tænkning, i særlig grad efter dets oversættelse til engelsk i 1991. Soja har foreslået, at dette labyrintiske, eklektiske, kalejdoskopiske og til tider tilsyneladende selvmodsigende værk skal læses som en stor polyfonisk fuga, hvor forskellige instrumenters simultane afspillen af forskellige melodier tilsammen udgør én samlet musikalsk komposition, således at der sker en spatialisering af teksten selv med heuristiske kredsende tilnærmelser til og kontek- 
stuelle repræsentationer af tekstens temaer (Soja 1996: 9). Lefebvre understreger i værket genkommende betydningen af en lokal levet erfaring af geografiske rum. En af Lefebvres helt centrale pointer er, at analysen af rummet skal foregå som en analyse af produktionen af rummet. Rum er ifølge Lefebvre ikke en ting, men snarere et sæt af relationer mellem ting (Lefebvre 1991 [1974]: 73).

Lefebvre forstår rummet som et socialt rum, hvor både 'det praktiske', 'det symbolske' og 'det imaginære' er indeholdt. Lefebvre danner en begrebslig triade, hvor han skelner mellem 'spatial praktik', 'rummets repræsentationer' og 'repræsentationernes rum'. Denne treklang forsøger at indfange tre forskellige aspekter af det sociale rum, der nok kan adskilles analytisk, men som i praksis befinder sig i et samspil. 'Spatial praktik' angår det erfarede praktiserede rum og de materielle sociale interaktioner, der bliver til og opretholdes i samspillet mellem daglige praksisser og rutiner i sociale relationer og institutionelle systemer (Lefebvre 1984 [1974]: 38). 'Rummets repræsentationer' angår ifølge Lefebvre 'det begrebne rum' (l'éspace concu) (Lefebvre 1984 [1974]: 38). Rummets repræsentationer konciperes af samfundets dominerende begrebsliggørende instanser og er knyttet til den dominerende samfundsorden og til de sociale koder, gennem hvilke vi filtrerer og forstår det materielle rum og den spatiale praksis. 'Repræsentationernes rum' angår 'det levede rum' (l'éspace vecu); som diverse brugere bestandigt skaber og genskaber gennem forskellige former for approprieringer af rummet som eksempelvis tilskrivning af symbolsk betydning, kunstnerisk bearbejdning, modificering af omgivelser, hverdagslivets rytmer, kulturel overlevering, individuel eller kollektiv historiefortælling og/eller dannelser af rum for modstand og opposition (Lefebvre 1984 [1974]: 38). Lefebvres triade er uhyre kompleks og begrebsbestemmelserne forskyder sig også, som blandt andet Soja har vist (Soja 1996), internt i værket. Triaden er motiveret af modstanden mod binære kategorier og entydige bestemmelser af rummets væsen, der risikerer at fryse fast i permanente strukturer.

\section{Den kritiske kulturgeografi}

Lefebvres rumanalyser skulle vise sig at blive afgørende inspirationskilde for kritiske kulturgeografer som eksempelvis Doreen Massey, Nina Smith og Tim Cresswell, der alle insisterer på individers eller gruppers 'ret til rum'. Arven fra Lefebvre består frem for alt i en indsigt $i$, at det rumlige er en integreret del af en social praksis og sociale processer, og omvendt at social praksis og sociale processer tilsvarende har en immanent rumlig dimension. Som tidligere nævnt argumenterede Edward Soja for en re-spatialisering af samfundsteorien og hævdede, at samfundsteorien har undertrykt og fornægtet spatialitetens betydning. De spor til 
en ny spatial epistemologi, som Soja lagde ud allerede i Postmodern Geographies - The Reassertion of Space in critical Social Theory (1989), kulminerer i Thirdspace - Journeys to Los Angeles and other Real-and-Imagined Places (1996). Det rum, der er tale om i den spatiale vending, er ifølge Soja det samfundsmæssigt skabte rum (Soja 2008: 252-253). I Sojas dekonstruktion af den privilegerede position tid og historie har haft i moderne samfundsteori, ses inspirationen fra Lefbvre blandt andet ved, at det netop er det socialt producerede rum, der skal rykkes ind i centrum af den analytiske bevidsthed. Soja er altså ude i et ærinde med tydelige politiske og samfundsmæssige implikationer. Rumlige processer er ifølge Lefebvre såvel som Soja samfundsmæssige processer.

En række kulturgeografer begyndte i løbet af 1980’erne at kritisere og stille spørgsmålstegn ved forsøgene på at praktisere, hvad der ifølge deres forståelse var en essentialistisk teori om stedet og en for statisk og konservativ konception af rummet. Disse geografer var påirket af marxisme, feminisme og poststrukturalisme og importerede til geografien metoder og debatter fra filosofi, litteraturteori, kulturstudier og antropologi (Duncan, Johnson \& Schein 2008 [2004]: 2). Den kritiske kulturgeografi annoncerede et nyt ægteskab mellem geografien og den kritiske teori. Man var i særlig grad optaget af at ville give stemme til divergerende subjektive og underordnede stemmer og begyndte at afsøge en mængde måder, hvorpå rum, mening, sociale hierarkier og magt er forbundet. Dette gjorde man blandt andet ved at udforske, hvordan identifikationen af specifikke steder er involveret i mekanismer, der tjener det formål at inkludere og ekskludere forskellige befolkningsgrupper og/eller måder at agere på.

Henri Lefebvre, Doreen Massey og Edward W. Soja er fælles om at mene, at rum skal konciperes som noget dynamisk, relationelt og socialt produceret. Forståelsen af rummet som socialt produceret fører hos Doreen Massey til, at også stedsbegrebet må redefineres, idet heller ikke stedet bør forstås som en fikseret ting med en stabil essens ${ }^{8}$. Et paradigmatisk eksempel på en sådan type af læsning er Doreen Masseys artikel "A global Sense of Place" (1994), hvori hun argumenterer for en ny konception af stedet som værende hybridt, åbent og porøst. At steder ikke har rødder, men ruter er kongstanken i Masseys tilgang. Det er værd at bemærke, at Massey kalder sin vidt berømte og hyppigt citerede tekst "A global sense of place" og ikke "A global sense of space". Hvor Soja temmelig konsistent taler om 'space', rykker insisteringen på det spatiale som socialt konstitueret hos Massey med over i omgangen med stedsbegrebet.

Massey fremhæver, ligesom blandt andre Mike Crang (Crang 2008) og Nigel Thrift, at begrebet rum må tænkes integreret med begrebet tid som "space-time" (Massey 1994: 2). Massey demonstrerer, hvordan den radikalt nye måde at for- 
stå rummet på kan bruges til at udfordre og kritisere eksklusive, essentialistiske definitioner af stedet. I stedet for et essentialistisk begreb om stedet, der har sin rod $i$ et statisk rumbegreb, vil Massey sætte et syn på stedet som en artikulation af de netværk af sociale relationer, der konstituerer det spatiale (Massey 1994). Stedet er ikke noget, der defineres internt inden for en afgrænset horisont, men derimod noget der i lige så høj grad konstitueres gennem forbindelser til instanser, som ligger uden for stedet. Med udgangspunkt i en anerkendelse af de komplekse transformationer af forholdet mellem det lokale og det globale forsøger Massey at redefinere betydningen af begreber som hjem, sted og lokalitet på globaliseringens præmisser. Hun forsøger desuden at overskride sociologiske diagnoser, der kendetegner det moderne individ som stedsløse og desorienterede. Diagnoser, der kan føres helt tilbage til Simmel, og som hun mener at kunne konstatere overvintret hos eksempelvis David Harvey og Fredric Jameson (Massey 1994: 162f). Masseys reservationer angående hjemløshedsdiskursen går på, at forestillingen om en fortidig umedieret erfaring af en uproblematisk hjemmehørenhed i verden er såvel nostalgisk som kontrafaktisk. Essayet "A place called home?" udkom første gang i New Formation i 1992, og det kan i dag konstateres, at den nuancering og opmærksomhed på stedsbegrebet, hun her efterlyser og selv praktiserer, i mellemtiden har vundet genhør og inspireret til efterfølgelse.

\section{Den fænomenologiske stedsteori}

En anden vigtig tradition, der i rigt mål trækkes på i den igangværende optagethed af menneskelivets rumlige dimensioner, ikke mindst når den spatiale vending adapteres af områder som antropologi, arkæologi og pædagogik, er fænomenologien. En række kulturgeografer og stedsteoretikere såsom Yi Fu Tuan, Edward Relph, Edward Casey og David Seamon har i forlængelse af filosoffer som Edmund Husserl, Martin Heidegger, Maurice Merleau-Ponty og Gaston Bachelard forsøgt at integrere indsigter fra fænomenologien og eksistensfilosofien i deres stedsteori. Den moderne fænomenologi som filosofisk udforskningsmåde tager sin begyndelse med udgivelsen af Husserls trebindsværk Logische Untersuchungen (1900-1901). Husserls tese er her, at al bevidsthed er kendetegnet ved intentionalitet (altså ved en rettethed mod en genstand). Bevidstheden er ifølge Husserl en intenderende instans, der i sin omgang med objektet på forskellige måder vil objektet. Vi har forskellige tilgange til fænomenerne, når vi henholdsvis elsker, lytter, tænker, foragter, bygger etc. Verden tager form efter den indstilling, vi har til den. Fænomenologiens opgave bliver følgelig at beskrive, hvordan forskellige genstande er knyttet til bestemte typer af bevidsthedsakter. 
Fænomenologien kan på forskellig vis bidrage til at belyse den komplekse levede erfaring af steder. Den fænomenologiske tradition har bidraget til stedsteorien på mindst to afgørende punkter. For det første gennem analyser af måder mennesker praktisk og emotionelt forbinder sig med og bebor steder. Dette perspektiv kan vi identificere som 'beboelsesperspektivet'. For det andet har fænomenologien været den afgørende metode til studier af måderne, hvorpå det forhold at vi er kropsligt situerede væsener, influerer vores måde at forstå og erfare steder på. Dette perspektiv kan vi kalde 'kropslighedsperspektivet' . Edmund Husserl, Jean-Paul Sartre og Merleau-Ponty udforsker på hver deres måde den præmis, at vores kropslige situerethed $\mathrm{i}$ verden bestemmer vores måde at være til og forstå verden på og er mulighedsbetingelse for den perceptuelle intentionalitet. Fænomenologiens og eksistensfilosofiens indflydelse på geografien fandt ikke mindst sted, da man i Nordamerika og England i 1960'erne og 1970'erne i et opgør med en positivistisk geografi udviklede en såkaldt humanistisk geografi (Hansen og Simonsen 2004: 64-65). Fænomenologien bidrager altså til forståelsen af spatialitetens betydning, idet den kommer med en række bud på, hvordan den menneskelige måde at være til og erfare verden på kan forstås ud fra en kropslig, kulturel og social indlejret væren-i-verden. Den fænomenologiske tradition er særligt givende, når det handler om at belyse menneskets emotionelle og praktiske forbundethed med dets fysiske omverden samt til at belyse stedets fundamentale betydning for vores erfaring af en eksistentiel forankring i verden. Det kan danne teoretisk baggrund for analyser af oplevede, fortolkede, erfarede og praktiserede steder. Stedet som "livsverdenens geografiske dimension" (Hansen og Simonsen 2004: 67) bliver i denne type analyser noget, der konstitueres gennem praksisser, emotioner, relationer, erindringer og forventninger. Endelig kan fænomenologien forankre os metodologisk og analytisk, fordi dens repræsentanter på forskellige vis udfolder og drager filosofiske og analytiske konsekvenser af, at vi altid allerede er til stede i den verden, vi søger at reflektere over. En pointe Heidegger mere and nogen anden har slået fast.

Den engelske antropolog Tim Ingold har i forlængelse af tænkere som netop Heidegger, Merleau-Ponty og James Gibson (1904-1979) vist, at bevidstheden er situeret $i$ et aktivt engagement $i$ verden. Dette at befinde sig på et sted betyder ifølge Ingold ikke primært at befinde sig på en lokalitet i rummet, men derimod at befinde sig på en sti af bevægelse. Denne sti udgør en del af et matrix af stier, der konstituerer regionen (Ingold 2000: 219). Kendskab er noget, der erfares horisontalt, og integreres ved at man bevæger sig rundt i en omgivelse. Erkendelse er noget, der erhverves løbende, mens man bevæger sig i rum og tid gennem verden og livet. Kendskab og erkendelse er som følge heraf bestandigt under konstruk- 
tion. Ingold har med sin teori om det horisontalt integrerede kendskab formået at give nyt liv til den fænomenologiske tradition, og har behandlet såvel 'kropslighedsperspektivet' som 'beboelsesperspektivet' på en måde, der er teoretisk opdateret og højst relevant. Mennesker kender, som vi allerede så belyst hos Heidegger og Merleau-Ponty, netop til noget gennem situationelle handlingskontekster. Ifølge Ingold har steder og landskaber i vores bevidsthed ikke lokalisationer, men historier. For den lokalkendte, der orienterer sig i sin fortrolige omverden, eksisterer steder ikke som koordinater på et mentalt landkortkort, men i kraft af menneskets situerethed og tidligere bevægelser i en bekendt kontekst.

\section{Kulturstudiernes praksisanalyser}

En række af fænomenologiens afgørende indsigter lever videre og operationaliseres i kulturstudiernes og geografiens praksisanalyser. I mere eller mindre bevidst forlængelse af den fænomenologiske tradition forsøger praksisgeografien, hverdagssociologien og den praksisorienterede kulturanalyse at udforske, hvordan vi kender og erfarer steder gennem kropslig, kontekstuel og situationel praksis. Vi så ovenfor, hvordan den kritiske kulturgeografi leverer en dialektisk forståelse af forholdet mellem rummet og det sociale, der viser, hvorledes steder og rum er socialt producerede, hybride og i bevægelse. Vi så ydermere, hvordan den fænomenologiske tradition leverer indsigter $i$, hvordan og med hvilke konsekvenser vi som kropslige væsner bebor og er indfældet i den verden, der omgiver os. Det kulturanalytiske praksisperspektiv tilføjer en forstærket globalt orienteret opmærksomhed på, hvordan steder - herunder ikke mindst såkaldte marginaliserede steder, er ( $\mathrm{g}$-)lokalt praktiserede, forhandlede og situerede. Det er indsigter, der allerede optræder i de to andre traditioner. Men hverdagssociologien hos eksempelvis Michel de Certeau og den non-repræsentationelle/mere-end-repræsentationelle geografi ${ }^{10}$ hos eksempelvis David Crouch og Nigel Thrift, tilføjer et skærpet analytisk mikrosociologisk perspektiv på tilegnelser og genforhandlinger af kulturelle betydningslag i globalt-lokale, materielle og medierede kontekster. Denne opmærksomhed på måderne, hvorpå vi 'gør steder', kan hjælpe os til at forstå og konkretisere sociale kulturelle fænomener og til at forstå, hvordan individer praktiserer, performer og forestiller sig steder i diverse kulturelle kontekster. Gennem disse kulturelle praksisser genforhandler og approprierer individerne kulturelle repræsentationer og forestillinger og skaber og erfarer mening i mødet med verden. 


\section{Hvornår er en vending en vending?}

I kølvandet på den sproglige vending har man talt om en række vendinger, som eksempelvis the performative turn, the interpretive turn, the reflexive turn, the postcolonial turn, the translational turn, the material turn, the pragmatic turn, the iconic turn og endelig the spatial turn. Det afføder potentielt spørgsmålet om, hvorvidt der eventuelt er gået inflation i begrebet turn og følgelig, hvor omfattende rækkevidden og holdbarheden af de enkelte vendinger måtte være. Det er imidlertid væsentligt at være opmærksom på, at flere af disse forskellige vendinger er internt forbundne, og at den spatiale vending kan ses som kondenserende indsigter fra flere af de øvrige vendinger. Der er eksempelvis bemærkelsesværdige interessefællesskaber og metodiske ligheder mellem dele af den performative vending og den spatiale vending og mellem den spatiale vending og den postkoloniale vending. Tilsyneladende ret forskellige felter argumenterer og opererer altså beslægtet. Der er indenfor flere områder sket en bevægelse fra at tale om mening til at tale om affekt (Whatmore 2006: 604) og en bevægelse fra at tale om, hvad ting betyder, til hvad ting gør (Ehn og Löfgren 2006: 15), og ikke mindst en bevægelse hen imod en priviligering af analyser af, hvad der sker i vores praktiske, situerede og materialiserede omgang med ting, ideer og fænomener.

Store dele af steds- og rumsteoretikerne har beslægtede interesser i materialitet og praksisformer til fælles med repræsentanter fra vendinger som the cultural turn, the practical turn og the performative turn. Deri kan ses et ønske om at flytte fokus fra den omfattende optagethed af repræsentation og sprog, som den sproglige vending medførte, til fordel for en optagethed af kulturelle fænomener som noget materielt situeret, hvor mening konstitueres gennem igangværende aktivitet. Hvor man med den sproglige vending blev optaget af, at påvise sproget som den strukturerede agent, bliver man med den spatiale vending optaget af at påvise rummet som en strukturerende agent. Det kunne derfor formodes, at den spatiale vending som postuleret etikette lever af polemisk at distancere sig fra den omfattende forudgående sproglige vending. Dette er imidlertid kun delvis tilfældet. Blandt andet fordi adskillige repræsentanter for den sproglige vending, som eksempelvis Wittgenstein, allerede var optaget af at vise, at også sproget får betydning gennem de praksisser, sammenhænge og situationer, hvori det optræder. Hvis vi vil forstå de polyfone måder, steder får betydning for os på, må vi forene analyser af praksis og materialitet med analyser af repræsentation og mediering. Vi må på én gang trække på og fastholde pointer blotlagt af den sproglige vending og samtidig overskride og komplementere denne i vores konkrete analyser.

Talen omkring en spatial vending indikerer, at der sker en flytning af fokus i den intellektuelle iagttagelse, opmærksomhed og metodik. Det er i øvrigt værd at 
bemærke, at begrebet vending selv er en spatial metafor, der vidner om erkendelsens egen spatiale struktur. Vi vender vores bevidsthed hen mod noget og væk fra noget andet. Vendinger behøver ikke nødvendigvis at forstås som opdagelser af noget radikalt nyt, men kan lige så vel konciperes som forskellige til dels samlede eller sammenfaldende kræfter, der giver fornyet opmærksomhed til fænomener og processer, der allerede længe har påkaldt sig analytisk opmærksomhed. At rum og sted i stigende grad bliver forskningsgenstande gør ikke i sig selv nødvendigvis en vending. En decideret vending kendetegnes normalt, om end ikke nødvendigvis, ved at være interdisciplinær, hvilket man i høj grad kan sige om den spatiale vending. Begrebet indebærer som udgangspunkt et kvalitativt spring i den metodiske og konceptuelle tilgang. Det kan man ligeledes sige om den spatiale vending. Det vil først om nogle år vise sig, $\mathrm{i}$ hvor høj grad den spatiale vending i mere omfattende grad skal vise sig at indebære et interdisciplinært kvalitativt spring i den metodiske og konceptuelle tilgang.

Diskussionerne omkring den spatiale vending har uundgåeligt ført til en række skriverier omkring, hvorvidt denne fortælling om rum- henholdsvis stedsbegrebets periodevise fortrængning og renæssance er plausibel. I denne forbindelse har flere indvendt, at hverken rum- eller stedsbegrebet har været dømt ude, men derimod indenfor flere felter som eksempelvis etnografi, antropologi og - af indlysende grunde - geografi længe har ført et blomstrende liv (Hard 2008). Ligesom kulturgeografien har vist sig adaptiv i forhold til andre videnskaber, har den haft stor succes med at eksportere sin viden til andre felter. Det gælder såvel teoretiske videnskabelige discipliner såsom videnskabshistorie, kulturteori, antropologi, arkæologi og sociologi som mere anvendte felter såsom forvaltning af kulturarv, turisme, arkitektur og miljøforvaltning. Visse geografer ser endog den spatiale vending som netop en succesfuld ekspansionshistorie fra geografiens side. Nogle geografer er kritiske overfor den spatiale vending, som de ser som et forsøg på at genopdage den dybe tallerken (Redepenning 2008). Andre har ment, at det er nødvendigt at advare mod, at den spatiale vending kan komme til at gentage tidsdeterminismens fejl under modsat fortegn og ende i vulgærrumlighed og rumdeterminisme (Günzel 2008: 220).

Til trods for at man som ovenfor demonstreret kan problematisere hvorvidt, og $i$ givet fald hvordan, det er berettiget at tale om en mere omfattende vending, så mener jeg, at det er indiskutabelt, at konceptualiseringen og rekonceptualiseringen af de spatiale begreber har vidtrækkende betydning. Måderne, hvorpå vi formulerer og konciperer disse begreber, er i radikal forstand med til at forme vores forståelse af det sociale rum og vores muligheder for at influere dets transformationer. 
Måden vi forstår situationelle betydningsdannelser på, har en række konsekvenser for fænomener som eksempelvis byplanlægning, kulturarvsforvaltning og spatiale uligheder og konflikter. Der er en lang række situationer, hvor en mere bevidst omgang med stedets multidimensionalitet er påkrævet, og hvor visse typer af mere endimensional stedsforståelse ikke slår til. Det gælder eksempelvis, når vi skal lave byplanlægning, når vi laver kulturarvsforvaltende monumenter og erindringssteder ihukommende historiske begivenheder, når vi vil skabe rum for meningsfulde interaktioner i det offentlige rum, når vi vil lave sygehuse, der ikke bare skal være fabrikker men helende omgivelser, når vi skal forvalte det multikulturelle samfund på en måde, der ikke ender i hierarkisk segregering og eksklusion. Når man først man er blevet opmærksom på spatialitetens betydningsdimensioner, bliver det også tydeligt, at ethvert sted har en kontekst, og igennem dets strukturer, former og repræsentationer indeholder og udtrykker igangværende fortællinger. Det handler for aktører, planlæggere og teoretikere i en konkret kontekst om at være sensitive over for, kunne læse, indgå i og respondere på allerede igangværende dialoger på en given lokalitet.

Vi ser i den type studier, den spatiale vending informerer og initierer, en forstærket analyse af, hvordan kulturelle fænomener praktiseres og transformeres i lokalt materialiserede og globalt medierede kontekster. Den spatiale vending kan medføre en styrkelse af vores spatiale bevidsthed og sans for stedernes mangetydige dimensioner, der kan bidrage til vores forståelse af den omgivende verden som en palimpsest af værdifulde betydningsspor, der rummer en verden af potentialer. Denne mangfoldighed af indsigter, som den igangværende fremvoksende spatiale tænkning rummer, er endnu ikke fuldt forløst. Men vi er vidne til en udvikling indenfor teorien, der bidrager til at muliggøre, at vi som analytikere og tænkere bliver bedre til at navigere i og værdsætte de spatiale dimensioner i menneskets mellemværende med verden.

\section{Litteratur}

Bachelard, Gaston (2003): Poetik des Raumes Fischer Taschenbuch Verlag Frankfurt am Main Bachmann-Medick, Doris (2006): “Cultural Turns - Neuorientierungen in den Kulturwissenschaften“ in Rowolts encyklopädie, Rowolts Taschenbuch Verlag 2006

Casey, Edward S. (1993): Getting Back into Place - Toward a Renewed Understanding of the PlaceWorld. Indiana University Press, Bloomington and Indianapolis

Casey, Edward S. (1998): The Fate of Place - a Philosophical History, University of California Press, Berkeley Los Angeles London

Certeau, Michel de (1984): The Practice of Everyday Life University of California Press Berke- 
ley, Los Angeles/London

Döring, Jörg und Thielmann, Tristan edd. (2008): Spatial Turn - Das Raumparadigma in den Kultur und Sozialwissenschaften, Transcript Verlag, Bielefeld

Eden, Stuart and Crampton W. Jeremy (2007): "Introduction" in Space, Knowledge and Power; Foucault and Geoghraphy, Ashgate

Fabian, Louise (2008a): "Stedets identitet til genforhandling - London som Postimperial metropol" in Imperialisme, Slagmark Tidsskrift for Idehistorie, nr. 51

Fabian, Louise (2008b): "Sygeplejens rum, rummenes sygepleje" in Perspektiverpå Pleje - Vardier i praksis, Torben E. Andreasen (red.), Forlaget Philosophia

Fabian, Louise (2009): Den spatiale tankning - en udforskning og anvendelse af analytiske potentialer $i$ den interdisciplinare rekonceptualisering af rum, sted og landskab (phd.-afhandling udkommer på Aarhus Universitetsforlag efterår 2010)

Falkheimar, Jesper \& Jansson, Andre (2006): Geographies of Communication - The Spatial Turn in Media Studies, Nordicom, Göteborg University

Finnegan (2008): "The Spatial Turn: geographical Approaches in the history of Science", Journal of the History of Biology Springer volume 41, number 2 June 2008

Foucault, Michel (1998 [1967]): "Andre Rum" in Slagmark nr. 27.

Foucault, Michel (1980): Power/Knowledge. Selected Interviews and Other Writings 1972-1977, Pantheon Books, New York

Goodchild, Michael F. and Janelle, Donald G. (2010) "Toward critical spatial thinking in the social sciences and humanities" in Geojournal (2010) 75:3-13

Hansen, Frank \& Kirsten Simonsen (2004): Geografiens videnskabsteori - in introducerende diskussion, Roskilde Universitetsforlag

Hard, Georg (2008): “Der Spatial Turn von der Geographie her beobachtet" in Döring, Jörg und Thielmann, Tristan (hrsg.): Spatial Turn - Das Raumparadigma in den Kultur und Sozialwissenschaften Transcript Verlag, Bielefeld

Jannson, André and Falkheimer, Jesper (2006): "Towards a Geography of Communication" in Falkheimer, Jesper and Jansson, André (eds.) Geographies of Communication - The Spatial Turn in Media Studies, Nordicom, Göteborg University

Gulson, Kalervo N. and Symes, Colin (2007) Spatial theories of education: policy and geography matters, Routledgem New York

Lefebvre, Henri (1991 [1974]): The Production of Space, Blackwell Publishing

Lorimer, Hayden (2005): "Cultural Geography: the busyness of being 'more-than-representational" in Progress in Human Geography 2005

Massey; Doreen (1994): Space, Place and Gender, Polity Press and Blackwell Publishers, Cambridge/Oxford

Redepenning, Marc (2008): “Eine selbst erzeugte Überraschung: Zur Renaissance von Raum als Selbstbeschribungsformel der Gesellschaft", in Döring, Jörg und Thielmann, Tristan (hrsg.): Spatial Turn - Das Raumparadigma in den Kultur und Sozialwissenschaften, Transcript Verlag, Bielefeld

Rorty, Richard (1992[1969]): The linguistic Turn: Essays in Philosophical Method, University of 
Chicago Press

Soja, Edward W. (1989): Postmodern Geographies - The Reassertion of Space in Critical Social Theory, Verso, London/New York

Soja, Edward (1996): Thirdspace - Journeys to Los Angeles and Other Real-and-Imagined Places, Blackwell Publishers

Soja, Edward W. (2008): "Vom "Zeitgeist" zum "Raumgeist"- New twists on the Spatial Turn“, in Döring, Jörg und Thielmann, Tristan (hrsg.), Spatial Turn - Das Raumparadigma in den Kultur und Sozialwissenschaften, Transcript Verlag, Bielefeld

Thrift, Nigel (2002 [1983]): "On the determination of social action in space and time", in The Spaces of Postmodernity, Michael J. Dear and Steven Flusty (eds.), Wiley-Blackwell

Thrift, Nigel (2004): "Performance and Performativity: A Geography of Unknown Lands" in A companion to Cultural Geography (eds.) James S Duncan, Nuala C. Johnson and Richard H. Schein, Blackwell Publishing

Thrift, Nigel (1996): Spatial Formations, Sage Publications, London Thousand Oaks, New Delhi

Whatmore, Sarah (2006): "Materialist returns: practising cultural geography in and for a more-than-human world”, Cultural Geographies 2006; 13; 600-609

Withers, Charles W. J. (2009): 'Place and the "Spatial Turn" in Geography and in History' in Journal of the History of Ideas, Volume 70, Number 4 (October 2009)_

\section{Noter}

1 Edward Sojas begreb 'Thirdspace' udvikles eksempelvis som et forsøg på at følge op på Henri Lefebvres opfordring til at undgå at tænke det spatiale bipolært (Soja 1996).

2 The spatial turn oversættes i nærværende artikel med den spatiale vending. Andre har også i nærværende nummer af Slagmark valgt at oversætte the spatial turn til den rumlige vending, den topologiske vending og den topografiske vending. Der er ligeledes i den internationale litteratur adskillige eksempler på en talen om topographical turn og en topological turn. Betegnelsen den spatiale vending foretrækkes også som en samlebetegnelse der inkluderer såvel optagetheden af rum- og stedsbegrebet. Valget af betegnelsen den spatiale vending placerer sig ydermere i forlængelse af Edward Sojas indkredsning af "the social production of human spatiality" (Soja 1999: 262). Soja foreslår termen spatialitet til at referere til den stigende opmærksomhed på rummet som socialt produceret og fortolket, der kendetegner den spatiale vending. Man kunne naturligvis argumentere med at' spatiality' blot kan oversættes med rumlighed, men det er også muligt at fastholde spatialiteten som et specifikt tema addraseret af netop den spatiale vending.

3 En udfoldet analyse af disse tre hovedspor kan findes i min PhD.afhandling Den spatiale tankning - en udforskning og anvendelse af analytiske potentialer $i$ den interdisciplinare rekonceptualisering af rum, sted og landskab.

4 Denne videnskabshistoriske kontekst for den spatiale vending er blandt andet blevet behandlet af Michael F. Goodchild og Donald G. Janelle i artiklen Toward critical spatial 
thinking in the social sciences and humanities.

5 Sojas arbejde er beslægtet med og inspirerer geografiske tænkere og samfundsteoretikere som blandt andre David Harvey, Neil Smith, Doreen Massey, Nigel Thrift, Manuell Castells, John Urry, Anthony Giddens og Kirsten Simonsen.

6 Om disciplin siger Foucault i oktober 1974 i en forelæsning afholdt på Institute for Social Medicin i Rio de Janeiro i Brasilien: "Discipline is, above all, analysis of space; it is individualization through space, the placing of bodies in an individualized space that permits classification and combinations" (Foucault 2007: 147). Det vrimler med geografisk tænkning i Foucaults værker: Arkitektoniske planer for og spatiale organiseringer af asyler, fængsler og byrum, den spatiale eksilering og eksklusion af syge og fattige, hospitalet som et terapeutisk instrument, disciplineringsmekanismernes rumlige udtryk, videnskabernes geografiske distribuering, ja sågar udviklingen af et nyt rumanalytisk begreb heterotopen.

7 Lefebvre leverer en marxistisk læsning, hvor den spatiale bevidsthed nødvendigvis må tage form af en politisk bevidsthed, der i tredje omgang må tage form af en kapitalismekritisk bevidsthed. I den efterfølgende neomarxistiske kritiske kulturgeografi er kapitalismekritikken mere nedtonet til fordel for blandt andet postkoloniale og feministiske læsninger af forskellige hegemoniske undertrykkelser af forskellige minoriteter og af læsninger af diverse kampe om retten til at udlægge, definere og påvirke rummet.

8 Den kritiske kulturgeografi, som Soja og Massey praktiserer, har rødder tilbage til Marx og Friedrich Engels (1820-1895). Hvor det ikke mindst var den sociale ulighed der virkede initierende for Marx og Engels, er den neomarxistiske kulturgeografi ofte motiveret af en indignation over den geografiske ulighed.

9 En mere udfoldet analyse af disse to positioner kan findes i min afhandling Den spatiale vending - en udforskning og anvendelse af analytiske potentialer $i$ den interdisciplinare rekonceptualisering af rum, sted og landskab (Fabian 2009).

10 Hayden Lorimer introducerer termen 'more-than-representational' i artiklen "Cultural Geography: the busyness of being 'more-than-representational". Termen introduceres som et opklarende korrektiv til Nigel Thrifts term 'non-repræsenational geography', med begrundelse i, at ordet 'non' $i$ Thrifts term har vist sig at foranledige forkerte associationer og misforståelser: "I prefer to think of 'more-than-representational' geography, the teleology of the original 'non'-title having proven an unfortunate hindrance" (Lorimer 2005: 84). 
